\title{
Pengenalan Gangguan Ginjal Melalui Iridologi Menggunakan Hidden Markov Model (HMM)
}

\author{
Reza Satria Rinaldi ${ }^{1 *}$, Wagiasih ${ }^{1 * *}$, Ika Novia Anggraini ${ }^{1}$ \\ ${ }^{1}$ Program Studi Teknik Elektro Fakultas Teknik Universitas Bengkulu \\ *E-mail: reza_s_r@unib.ac.id, **E-mail: wagiasih87@gmail.com
}

\begin{abstract}
Iridology has not been widely applied for the recognition of kidney disorders. identification of kidney disorders through iris image using iridology chart, can make it easier to make diagnosis to find out about kidney disorders. The method used in the process of recognition of kidney disorders through iridology is the Hidden Markov Model (HMM) method, with a HMM parameter determination system using the calculation of the koefisien Singular Value Decomposition (SVD) coefficient. The size of the codebook used is 7 , i.e. 16, 32, 64, 128, 256, 512 and 1024. Different sizes of codebooks will result in different recognition times. The time needed will be longer when the size of the codebook is getting bigger. The accuracy of the process of recognition of kidney disorders through iridology using the HMM method in this study is $68.75 \%$ for codebook $16,87.5 \%$ for codebook 32, $100 \%$ for codebook 128 and $100 \%$ for codebook 512.
\end{abstract}

Keywords : iridology, codebook, image processing, singular value decomposition (SVD), Hidden Markov Model (HMM).

Iridologi belum banyak diaplikasikan untuk pengenalan gangguan ginjal. Pengenalan penyakit ginjal melalui citra iris mata menggunakan chart iridologi, dapat mempermudah dalam melakukan diagnosis untuk mengetahui adanya gangguan ginjal. Metode yang digunakan dalam proses pengenalan gangguan ginjal melalui iridologi adalah metode Hidden Markov Model (HMM), dengan sistem penentuan parameter HMM menggunakan perhitungan koefisien Singular Value Decomposition (SVD). Ukuran codebook yang digunakan ada 7, yaitu 16, 32, 64, 128, 256, 512 dan 1024. Ukuran codebook yang berbeda akan menghasilkan waktu pengenalan yang berbeda. Waktu yang dibutuhkan akan semakin lama ketika ukuran codebook semakin besar. Akurasi proses pengenalan gangguan ginjal melalui iridologi menggunakan metode HMM pada penelitian ini adalah $68.75 \%$ untuk codebook 16, $87.5 \%$ untuk codebook 32, 100\% untuk codebook 128 dan $100 \%$ untuk codebook 512.

Kata kunci: iridologi, codebook, pengolahan citra, singular value decomposition (SVD), Hidden Markov Model (HMM).

\section{Pendahuluan}

Penderita Gangguan ginjal tidak dapat diketahui secara langsung dan gejala yang ditimbulkan sering kali diabaikan. Hal ini menyebabkan banyaknya penderita gangguan ginjal di Indonesia. Pada tahun 2013 ada 504.248 jiwa yang menderita gagal ginjal kronis [1]. Keadaan ini menunjukan bahwa penderita gangguan ginjal di Indonesia masih sangat tinggi. Penyebabnya tidak hanya dari pola hidup yang kurang mengkonsumsi air, namun kurangnya kesadaran untuk mengetahui gejala-gejala gangguan ginjal dan memeriksakan keadaan ginjal.

Iridologi adalah ilmu yang mendiagnosis berbagai penyakit sistemik melalui analisis warna, struktur, karakteristik, dan perubahan iris pada mata manusia. Sebuah penelitian melakukan analisis terhadap total 36 kajian terkait iridologi yang diterbitkan tahun 1980 hingga 2012. Berdasarkan hasil penelitian tersebut, kajian tentang hubungan susunan iris dengan penyakit memiliki hasil yang signifikan. Karakteristik iris secara struktural berhubungan dengan kepribadian tertentu [2].

Sebuah penelitian yang bertujuan untuk mengembangkan basis data gangguan usus besar berdasarkan peta iridologi telah dilakukan. Subjek untuk memverifikasi basis data adalah sejumlah sukarelawan mahasiswa secara acak. Setelah sistem memperoleh hasil, subjek divalidasi melalui pemeriksaan medis di rumah sakit. Persentase kesalahan basis data iris untuk gangguan usus besar sebesar $8 \%$. Basis data iris ini diusulkan untuk membantu dokter dalam mendeteksi gangguan usus besar menggunakan pengolahan citra. Untuk mendapatkan hasil yang lebih baik, diperlukan lebih banyak basis data iris [3].

Sebuah sistem untuk mengidentifikasi iris mata individu dilakukan dengan memanfaatkan metode Hidden Markov Model (HMM). Uji coba menggunakan 50 buah citra mata kanan dari 10 individu yang berbeda. Tingkat keberhasilan dihitung dengan memvariasikan ukuran codebook dan jumlah ujiing masing-masing citra iris mata. Tingkat akurasi yang dihasilkan untuk jumlah ujiing 3 sebesar 95\% pada ukuran codebook 32 dan 


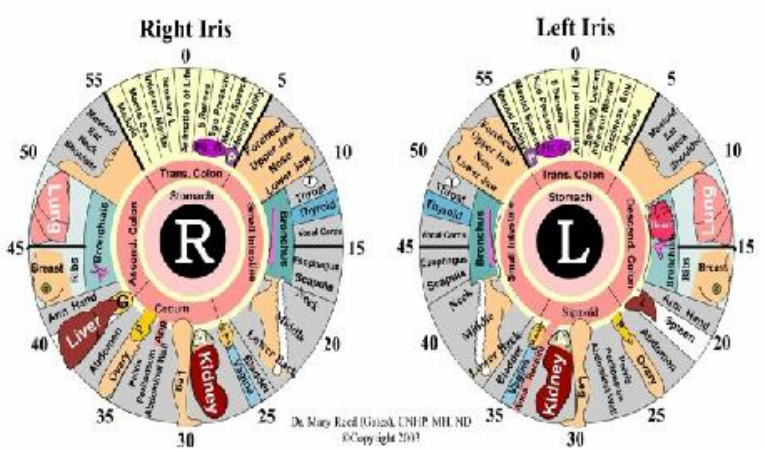

Gambar 1. Chart Iridologi [8]

$100 \%$ pada ukuran codebook 64. Untuk jumlah ujiing 4, tingkat akurasi yang dihasilkan sebesar $100 \%$ pada ukuran codebook 32 dan 64 [4].

Penelitian untuk memvalidasi penggunaan iridologi untuk mendiagnosis kelainan ginjal telah dilakukan. Dalam penelitian dilakukan evaluasi terhadap dua kelompok subjek, yaitu 168 subjek yang tanpa kelainan ginjal dan 172 subjek dengan gagal ginjal kronis. Analisis wavelet dan dan sistem inferensi Neuro-Fuzzy Adaptif digunakan dalam memproses dan mengklasifikasikan citra iris. Hasil penelitian menunjukkan tingkat kebenaran diagnosisis sebesar $82 \%$ untuk subjek dengan gagal ginjal kronis dan sebesar 93\% untuk subjek yang tanpa kelainan ginjal [5].

Berdasarkan penelitian-penelitian di atas, maka gangguan ginjal dapat juga didiagnosis menggunakan iridologi. Dalam penelitian ini, diagnosis gangguan ginjal dilakukan menggunakan pengolahan citra terhadap iris mata. Citra iris mata digitalisasi dan selanjutnya diolah dengan menggunakan metode HMM untuk proses analisis hasil.

\section{MATERIAL DAN METODE}

\section{A. Iridologi}

Iridologi telah ada selama sekitar 100 tahun. Meskipun demikian, masih banyak kontroversi terkait kegunaannya dalam menentukan masalah kesehatan [6]. Terdapat 2 hipotesis utama iridologi. Pertama, "Iris terlihat melalui perubahan pigmen dan struktur, kondisi abnormal jaringan dalam tubuh manusia. Kedua, "Iris secara reflect sesuai dengan topografi organisasi sistematis jaringan utama tubuh [7]. Chart Iridologi seperti pada Gambar 1, digunakan oleh praktisi iridologi. Iris kanan (right iris) digunakan untuk mendiagnosis jaringan tubuh sebelah kanan dan iris kiri (left iris) digunakan untuk mendiagnosis jaringan tubuh sebelah kiri.

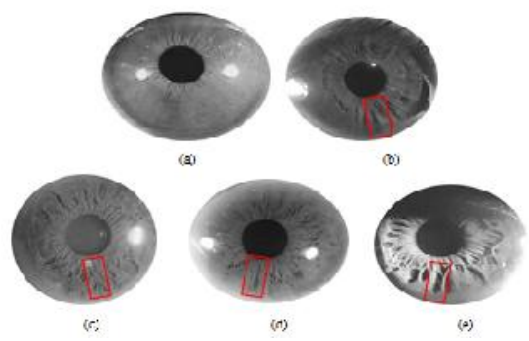

Gambar 2. Sampel Pengujian (a) Sampel Normal (b) Sampel KM Mata Kanan (c) Sampel BG Mata Kanan (d) Sampel GGK Mata Kiri (e) Sampel GGA mata Kiri

\section{B. Sampel Pengujian}

Ganguan ginjal sering terjadi akibat dari ginjal yang sudah tidak berfungsi dengan normal. Beberapa ganguan ginjal yang sering terjadi adalah sebagai berikut [9]:

1. Gagal Ginjal Kronik (GGK)

2. Gagal Ginjal Akut (GGA)

3. Diabetes Mellitus (DM)

4. Batu Saluran Kemih (BSK)

Pada Gambar 2. dapat dilihat sampel pengujian citra iris mata. Penentuan sampel ini didasarkan pada 2 hal, yaitu sampel diambil dari orang yang menderita gangguan ginjal dan berdasarkan chart iridologi. Gangguan ginjal ditunjukkan pada bagian kotak merah. Sampel pada Gambar 2.(a) merupakan sampel mata normal normal, yaitu yang tidak mengalami gangguan ginjal. Pada iris normal tidak terdapat kerusakan atau garis-garis. Sampel pada Gambar 2.(b) merupakan sampel mata dengan gangguan kencing manis (KM) atau diabetes mellitus (DM). Kerusakan pada sampel iris ini hanya berupa lipatan-lipatan. Untuk gangguan batu ginjal (BG) atau batu saluran kemih (BSK), kerusakan iris dapat dilihat pada Gambar 2.(c) dan untuk iris mata dengan ganguan gagal ginjal dapat dilihat pada Gambar 2.(d) dan (e), dapat dilihat pada iris kerusakannya parah dan seperti terbentuk lubang-lubang. Semua sampel iris mata pada Gambar 2.(b)-(e) merupakan sampel yang diambil dari orang yang menderita gangguan ginjal. Pasien-pasien tersebut memang sudah terdiagnosa sebagai penderita gangguan ginjal.

Sampel yang digunakan merupakan citra grayscale dari iris mata sebenarnya. Citra adalah representasi, kemiripan atau imitasi dari suatu objek atau benda. Citra terbagi 2 yaitu ada citra yang bersifat analog dan ada citra yang bersifat digital. Citra analog adalah citra yang bersifat kontinu seperti gambar pada monitor televisi, foto sinar X, hasil CT Scan dan lain-lain. Sedangkan pada citra digital adalah citra yang dapat diolah oleh 


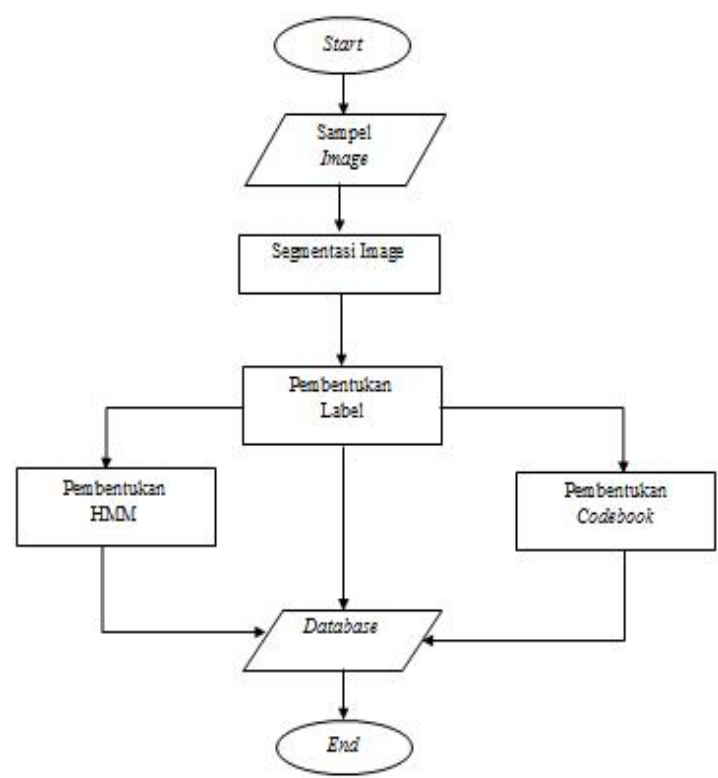

Gambar 3. Diagram Alir Pembentukan Basis Data

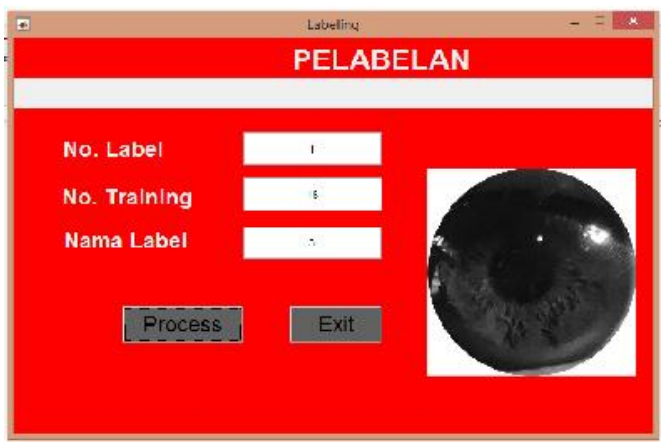

Gambar 4. Tampilan Proses Pelabelan

komputer [10]. Grayscale merupakan proses mengubah citra warna menjadi citra dengan skala keabuan digunakan dalam image processing untuk menyederhanakan model citra agar berukuran lebih kecil dibandingkan dengan citra sebelumnya. Citra hasil grayscale memiliki format grayscale 8 bit $\left(2^{8}=256\right.$ derajat keabuan) yang memiliki level intensitas yang sama untuk tiap-tiap layernya [11]

\section{Basis Data}

Basis data (database) merupakan data yang akan digunakan sebagai acuan pada saat proses pengenalan gangguan ginjal saat pengujian. Basis data dapat terbentuk dengan melakukan beberapa tahap, yaitu pelabelan, pembentukan codebook dan pembentukan HMM. Masing-masing tahapan tersebut akan menghasilkan basis data, yaitu basis data sampel, basis data codebook dan basis data HMM. Diagram alir pembentukan basis data dapat dilihat pada Gambar 3 .

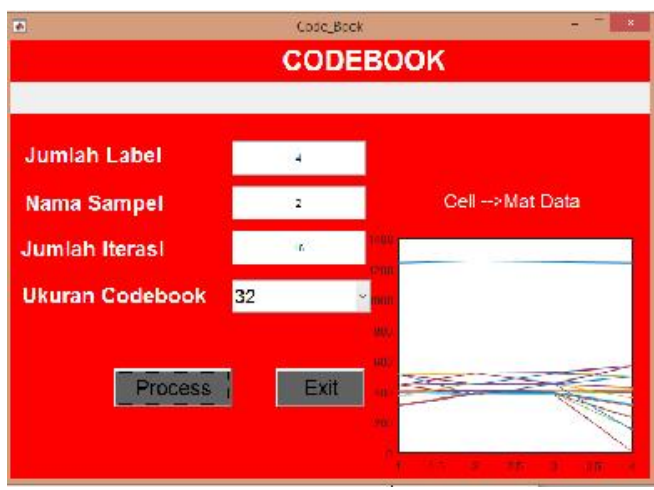

Gambar 5. Tampilan GUI pembentukan codebook

\section{Pembentukan Label}

Proses pelabelan akan dilakukan di Matlab dengan menggunakan GUI Matlab. Pada program pelabelan terdapat tiga input, yaitu nomor label, nomor ujiing dan nama label. Tampilan proses pelabelan dapat dilihat pada Gambar 4.

Pada proses pelabelan, input gambar iris adalah iris dalam bentuk grayscale dan output yang dihasilkan adalah data matrik dari iris yang sudah dalam bentuk polarisasi. Data matrik yang dihasilakan akan disimpan dalam bentuk *.mat dan dijadikan sebagai basis data untuk proses selanjutnya.

\section{E. Pembentukan Codebook}

Pembentukan codebook bertujuan untuk membandingkan output pengenalan gangguan ginjal, yaitu sebagai pembanding dengan mengubah ukuran dari codebook itu sendiri. Pada penelitian ini, ukuran codebook yang akan digunakan ada 7, yaitu 16, 32, 64, 128, 256, 512 dan 1024.

Pembentukan codebook dibuat di GUI Matlab dengan 4 input, yaitu nama sampel, jumlah label, jumlah iterasi dan ukuran codebook. Nama sampel yang digunakan harus sama dengan nama yang sudah tertera pada saat proses pelabelan dan jumlah label adalah banyaknya label yang akan diproses sedangkan iterasi adalah jumlah perulangan yang akan dilakukan dalam satu proses untuk satu sampel. Tampilan GUI pembentukan codebook dapat dilihat pada Gambar 5.

\section{F. Parameter HMM}

HMM adalah model statistik dimana suatu sistem yang dimodelkan diasumsikan berupa proses Markov dengan parameter-parameter yang belum diketahui dan parameter-parameter yang tersembunyi tersebut harus ditentukan dari parameter yang abservable. Parameter model yang diambil kemudian dapat digunakan untuk keperluan analisa selanjutnya, misalnya untuk aplikasi pengolahan citra[12].

Parameter HMM ditentukan menggunakan perhitungan koefisien Singular Value Decomposition 
(SVD). Algoritma SVD dapat dilihat dalam persamaan (1) dan persamaan (2) [13].

$$
\begin{aligned}
& X=U S V^{T} \\
& X_{m \times n}=[U]_{m \times n} \cdot[S]_{n \times n} \cdot\left[V^{T}\right]_{n \times n}
\end{aligned}
$$

dengan: $\mathrm{U}=$ matrik ortogonal berukuran $\mathrm{m} \times \mathrm{n}$

$\mathrm{S}=$ matrik diagonal berukuran $\mathrm{n} \times \mathrm{n}$

$\mathrm{V}^{\mathrm{T}}=$ matrik ortogonal berukuran $\mathrm{n} \times \mathrm{n}$

Dalam perhitungan SVD, pertama-tama perlu dilakukan penentuan banyaknya blok yang akan digunakan. Proses ini disebut juga dengan ekstraksi blok, yang dapat dilakukan menggunakan persamaan (3) [13].

$$
T=\frac{H-L}{L-P}+1
$$

dengan: $\mathrm{P}=$ Panjang piksel yang overlap dari dua blok

$$
\mathrm{L}=\text { Panjang piksel dalam blok }
$$$$
\mathrm{H}=\text { Panjang piksel gambar }
$$

Pemilihan ukuran $\mathrm{L}$ dan $\mathrm{P}$ dapat mempengaruhi keakuratan dalam sistem pengenalan. Setelah menghitung nilai $\mathrm{T}$, maka dapat dihitung nilai eigen dan vektor eigen dari $X X^{T}$ dan $X^{T} X$. Vektor eigen dari $X X^{T}$ bentuk kolom dari $\mathrm{U}$, sedangkan vektor eigen dari $X^{T} X$ suatu bentuk kolom V. Selain itu, nilai-nilai singular $\left(S V_{\mathrm{S}}\right)$ di $\mathrm{S}$ adalah akar kuadrat dari nilai eigen $X X^{T}$ atau $X^{T} X$ [13].

Koefisien SVD akan membangun vektor observasi $X=\left(x_{1}, x_{2}, \ldots, x_{n}\right)$, tetapi koefisien tersebut belum bisa dimodelkan oleh HMM sehingga perlu dilakukan kuantisasi vektor. Hal ini biasa dilakukan dengan proses pembulatan, pemotongan, atau proses yang lain. Misalkan sebuah barisan akan dikuantisasi ke dalam tingkat yang berbeda, sehingga perbedaan antara dua nilai kuantitatif akan menjadi persamaan (4) [13].

$$
\Delta_{i}=\frac{\left(x_{i} \max -x_{i} \min \right)}{D_{i}}
$$

Setelah diketahui $\Delta_{i}$ komponen $x_{i}$ akan digantikan dengan nilai kuantisasi seperti pada persamaan (5) [13].

$$
q_{t}=\frac{x_{i}-x_{i} \min }{\Delta i}
$$

Pada proses HMM di GUI Matlab ini, saat nama sampel diisi dan Select I/P, maka akan terkonfirmasi apakah codebook dalam keadaan aktif atau tidak aktif. Ketika codebook aktif, maka dapat dilanjutkan ke proses selanjutnya yaitu dengan mengklik proses dan akan didapat hasil seperti pada Gambar 6.

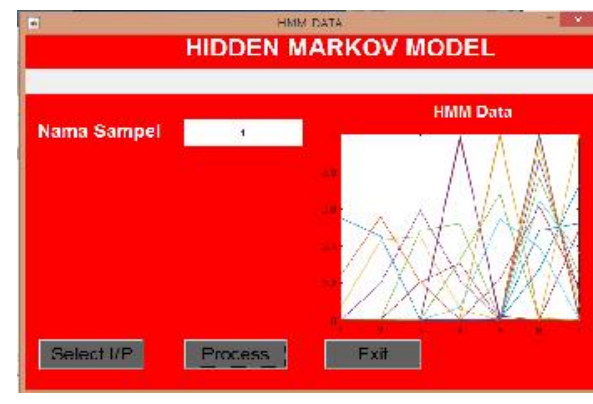

Gambar 6. Hasil Proses Hidden Markov Model

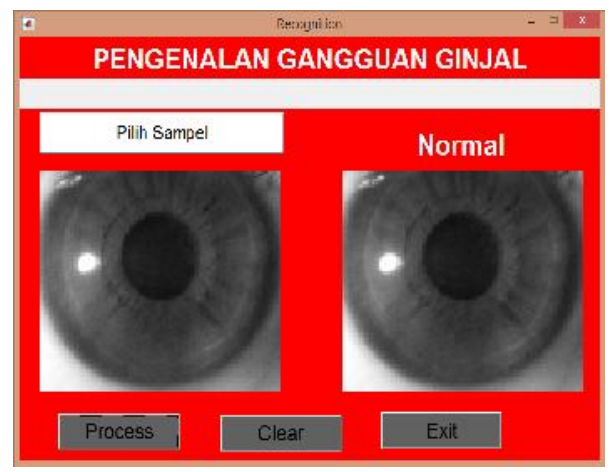

Gambar 7. GUI Pengenalan pada Saat Dijalankan

\section{G. Proses Pengenalan}

Proses pengenalan merupakan proses uji untuk sampel itu sendiri atau sampel yang baru. Pada proses ini akan ada 3 input, yaitu input sampel, file codebook dan file HMM. Gambar 7. memperlihatkan Tampilan GUI untuk proses ini .

Ketika proses dijalankan, maka akan ditampilkan sampel dan hasil berupa nama gangguan ginjal dari sampel tersebut dengan waktu pengenalan bergantung pada besar ukuran codebook yang digunakan. Pada Gambar 7. terdapat tiga tombol, yaitu process, clear dan exit. Tombol process berfungsi untuk eksekusi sampel yang sudah dipilih, clear berfungsi untuk menghapus sampel yang telah dieksekusi dan exit berfungsi untuk menutup GUI pengenalan gangguan ginjal

\section{Hasil Dan Pembahasan}

\section{A. Hasil Segmentasi Sampel}

Segmentasi merupakan proses pertama untuk menjadikan sampel iris mata lebih jelas dan lebih tampak garis-garis pada iris mata. Setiap sampel harus melalui proses segmentasi agar dihasilkan sampel dengan citra keabuan yang sama sehingga memudahkan untuk proses pengujian selanjutnya. Data sampel ini merupakan sampel train yang akan dijadikan basis data. 
TABEL 1

Hasil SEgmentasi SAMPEL Train

\begin{tabular}{llll}
\hline Kategori & \multicolumn{1}{c}{ Sampel Grayscale } \\
\hline GGA \\
(S1)
\end{tabular}

TABEL 2

Basis Data Pengujian Codebook 16 dan 32

\begin{tabular}{|c|c|c|c|c|c|c|c|c|c|}
\hline \multicolumn{5}{|c|}{ Codebook 16} & \multicolumn{5}{|c|}{ Codebook 32} \\
\hline S1 & S2 & S3 & S4 & S5 & S1 & S2 & S3 & S4 & S5 \\
\hline 1238 & 1238 & 1244 & 1242 & 1243 & 1244 & 1249 & 1244 & 1249 & 1237 \\
\hline 406 & 406 & 405 & 410 & 411 & 405 & 410 & 405 & 416 & 405 \\
\hline 398 & 398 & 404 & 410 & 473 & 405 & 409 & 404 & 409 & 405 \\
\hline 398 & 398 & 397 & 410 & 403 & 397 & 409 & 397 & 409 & 397 \\
\hline 390 & 390 & 396 & 402 & 402 & 397 & 402 & 397 & 402 & 396 \\
\hline 390 & 390 & 396 & 402 & 395 & 390 & 402 & 396 & 402 & 389 \\
\hline 390 & 313 & 389 & 402 & 395 & 389 & 395 & 389 & 402 & 389 \\
\hline 383 & 312 & 388 & 395 & 395 & 389 & 394 & 389 & 394 & 389 \\
\hline 382 & 312 & 388 & 395 & 395 & 389 & 394 & 389 & 394 & 381 \\
\hline 382 & 305 & 381 & 395 & 388 & 381 & 387 & 382 & 394 & 311 \\
\hline 382 & 305 & 311 & 388 & 458 & 381 & 387 & 381 & 394 & 304 \\
\hline 375 & 375 & 381 & 387 & 389 & 381 & 387 & 311 & 387 & 303 \\
\hline 445 & 375 & 374 & 457 & 389 & 451 & 387 & 304 & 387 & 373 \\
\hline 444 & 444 & 374 & 457 & 458 & 450 & 379 & 374 & 457 & 373 \\
\hline 514 & 513 & 443 & 457 & 451 & 520 & 380 & 443 & 457 & 373 \\
\hline 514 & 512 & 442 & 457 & 450 & 520 & 450 & 443 & 457 & 435 \\
\hline
\end{tabular}

TABEL 3

Basis Data Pengujian Codebook 128 dan 512

\begin{tabular}{rrrrrr|rrrr|c}
\hline \multicolumn{1}{c}{ Codebook 128 } & \multicolumn{6}{c}{ Codebook 512 } \\
\hline S1 & S2 & S3 & S4 & S5 & S1 & S2 & S3 & S4 & S5 \\
\hline 1238 & 1243 & 1249 & 1244 & 1249 & 1249 & 1238 & 1255 & 1243 & 1205 \\
406 & 411 & 418 & 405 & 410 & 417 & 406 & 485 & 411 & 443 \\
399 & 403 & 412 & 404 & 410 & 410 & 399 & 485 & 403 & 443 \\
398 & 403 & 335 & 397 & 402 & 410 & 398 & 416 & 403 & 513 \\
321 & 403 & 334 & 396 & 402 & 333 & 391 & 411 & 396 & 513 \\
321 & 396 & 396 & 396 & 402 & 326 & 321 & 335 & 395 & 513 \\
313 & 395 & 396 & 389 & 395 & 326 & 313 & 334 & 388 & 443 \\
313 & 395 & 389 & 388 & 395 & 388 & 313 & 326 & 388 & 373 \\
305 & 388 & 318 & 388 & 395 & 388 & 305 & 389 & 388 & 296 \\
235 & 388 & 312 & 381 & 388 & 388 & 235 & 318 & 381 & 366 \\
157 & 388 & 242 & 311 & 387 & 381 & 228 & 311 & 311 & 435 \\
87 & 388 & 304 & 381 & 388 & 381 & 157 & 241 & 310 & 435 \\
10 & 381 & 304 & 374 & 381 & 381 & 10 & 234 & 373 & 436 \\
291 & 380 & 374 & 374 & 381 & 374 & 10 & 304 & 373 & 436 \\
780 & 450 & 443 & 443 & 450 & 374 & 149 & 374 & 443 & 436 \\
779 & 450 & 512 & 442 & 450 & 443 & 358 & 436 & 443 & 505 \\
\hline
\end{tabular}

Data sampel train terdiri dari 5 sampel, yaitu gagal ginjal akut (GGA/S1), gagal ginjal kronis (GGK/S2), batu ginjal (BG/S3), kencing manis (KM/S4) dan normal (S5). Hasil segmentasi yang diambil ini adalah hasil
TABEL 4

Pengaruh WaKtu Terhadap UKuran Codebook

\begin{tabular}{|c|c|c|c|c|c|c|}
\hline \multirow{3}{*}{ No } & \multirow{3}{*}{ Kategori } & \multicolumn{5}{|c|}{ Waktu Pengenalan (detik) } \\
\hline & & \multicolumn{5}{|c|}{ Codebook (bit) } \\
\hline & & 16 & 32 & 128 & 256 & 512 \\
\hline \multirow{5}{*}{1} & \multirow{5}{*}{$\begin{array}{c}\text { GGA } \\
\text { (S1) }\end{array}$} & 1.6 & 1.8 & 2.0 & 3.9 & 21.1 \\
\hline & & 1.7 & 1.7 & 2.2 & 3.8 & 20.9 \\
\hline & & 1.6 & 1.7 & 2.0 & 3.8 & 20.8 \\
\hline & & 1.6 & 1.6 & 2.0 & 3.8 & 20.6 \\
\hline & & 1.7 & 1.7 & 2.1 & 3.9 & 20.8 \\
\hline \multirow{7}{*}{2} & \multirow[t]{2}{*}{ Rata-rata } & 1.6 & 1.7 & 2.1 & 3.8 & 20.8 \\
\hline & & 2.4 & 2.5 & 2.7 & 4.6 & 26.7 \\
\hline & \multirow{4}{*}{$\begin{array}{c}\text { GGK } \\
\text { (S2) }\end{array}$} & 2.4 & 2.4 & 2.8 & 4.9 & 25.7 \\
\hline & & 2.3 & 2.3 & 2.7 & 5.2 & 26.6 \\
\hline & & 2.4 & 2.4 & 2.7 & 5.0 & 26.5 \\
\hline & & 2.3 & 2.5 & 2.8 & 5.2 & 25.9 \\
\hline & \multirow[t]{2}{*}{ Rata-rata } & 2.4 & 2.4 & 2.7 & 5.0 & 26.8 \\
\hline \multirow{5}{*}{3} & & 3.6 & 3.7 & 3.6 & 5.4 & 25.6 \\
\hline & \multirow{4}{*}{$\begin{array}{l}\text { BG } \\
\text { (S3) }\end{array}$} & 3.7 & 3.7 & 3.8 & 5.6 & 25.2 \\
\hline & & 3.7 & 3.5 & 3.7 & 5.6 & 24.8 \\
\hline & & 3.7 & 3.2 & 3.7 & 5.7 & 25.5 \\
\hline & & 3.8 & 3.4 & 3.7 & 5.5 & 25.3 \\
\hline \multirow{7}{*}{4} & \multirow[t]{2}{*}{ Rata-rata } & 3.7 & 3.5 & 3.7 & 5.6 & 25.3 \\
\hline & & 4.0 & 4.4 & 5.4 & 6.3 & 29.4 \\
\hline & \multirow{4}{*}{$\begin{array}{l}\text { KM } \\
\text { (S4) }\end{array}$} & 4.0 & 4.6 & 5.5 & 6.3 & 28.8 \\
\hline & & 4.0 & 4.5 & 5.5 & 6.2 & 28.7 \\
\hline & & 4.1 & 4.5 & 5.6 & 6.2 & 28.8 \\
\hline & & 4.1 & 4.4 & 5.4 & 6.2 & 28.8 \\
\hline & Rata-rata & 4.0 & 4.5 & 5.5 & 6.2 & 28.9 \\
\hline
\end{tabular}

grayscale. Masing-masing sampel grayscale terdiri dari empat sampel yang diambil dari orang yang normal dan penderita gangguan ginjal. Proses ini menggunakan matlab dan hasilnya dapat dilihat pada Tabel 1 .

\section{B. Hasil Uji Coba Codebook}

Hasil dari pengujian ini diambil dari 5 buah sampel, yaitu S1, S2, S3, S4 dan S5 dengan variasi ukuran codebook 16, 32, 128 dan 512. Hasil pengujian ini diperlihatkan dalam Tabel 2 dan Tabel 3.

Pada masing-masing tabel dapat dilihat angkaangka dari proses pembentukan basis data codebook. Pada masing-masing tabel memiliki nilai maksimum, yaitu berkisar 1200-1255. Nilai ini merupakan nilai yang diambil dari masing-masing sampel.

\section{Hasil Pengujian Waktu}

Pengujian ini bertujuan untuk mengetahui pengaruh ukuran codebook terhadap proses pengenalan gangguan ginjal. Pengujian dilakukan pada sampel S1, S2, S3, dan S4 menggunakan stopwatch dan masing-masing sampel dilakukan perulangan sebanyak 5 kali. Selanjutnya dicari nilai rata waktu yang diperlukan untuk satu buah sampel dan variasi ukuran codebook. Pada pengujian ini digunakan ukuran codebook 16, 32, 128, 256 dan 512. Hasil pengujian waktu ini dapat dilihat pada Tabel 4.

Berdasarkan Tabel 4. dapat dilihat bahwa semakin besar ukuran codebook, maka waktu yang diperlukan untuk menyelesaikan proses akan semakin lama. Hal ini karena semakin besar ukuran codebook, maka nilai dari bit yang digunakan akan semakin besar pula sehingga membutuhkan waktu yang lebih lama. Berdasarkan 
Tabel 4. dapat dilihat juga bahwa perbedaan sampel juga mempengaruhi waktu. Sampel S1 memiliki waktu penyelesaian proses yang relatif cepat dan sampel S4 memiliki data waktu yang relatif lebih lama daripada dengan sampel S1, S2 dan S3. Hal ini karena saat proses sampel S1 hanya akan terbentuk database untuk sampel S1, sementara saat proses sampel S4 akan terbentuk database sampel S4 yang disertai dengan sampel S1, S2 dan S3

\section{Hasil Perhitungan Parameter HMM}

Parameter yang akan digunakan adalah 2 koefisien matrik $S$ dan koefisien pertama matrik $U$, yaitu fitur $\left(\mathrm{U}_{11}, \mathrm{~S}_{11}, \mathrm{~S}_{22}\right)$ untuk blok_1 sampai dengan blok_9. Nilai fitur yang terbentuk adalah sebagai berikut.

$$
\begin{aligned}
& {\left[U_{11} S_{11} S_{22}\right]_{1}=\left[\begin{array}{rrl}
0 & 255.0863 & 38.5746
\end{array}\right]} \\
& {\left[U_{11} S_{11} S_{22}\right]_{2}=\left[\begin{array}{lll}
0.2841 & 286.8763 & 45.1109
\end{array}\right]} \\
& {\left[U_{11} S_{11} S_{22}\right]_{3}=\left[\begin{array}{lll}
0.2351 & 310.0145 & 46.9893
\end{array}\right]} \\
& {\left[U_{11} S_{11} S_{22}\right]_{4}=\left[\begin{array}{lll}
0.2373 & 106.7848 & 14.3527
\end{array}\right]} \\
& {\left[U_{11} S_{11} S_{22}\right]_{5}=\left[\begin{array}{lll}
0.2313 & 114.7127 & 15.1658
\end{array}\right]} \\
& {\left[U_{11} S_{11} S_{22}\right]_{6}=\left[\begin{array}{lll}
0.2539 & 121.8483 & 16
\end{array}\right]} \\
& {\left[U_{11} S_{11} S_{22}\right]_{7}=\left[\begin{array}{lll}
0.2881 & 128.4017 & 17.2916
\end{array}\right]} \\
& {\left[U_{11} S_{11} S_{22}\right]_{8}=\left[\begin{array}{lll}
0.2929 & 134.2051 & 17.2627
\end{array}\right]} \\
& {\left[U_{11} S_{11} S_{22}\right]_{9}=\left[\begin{array}{lll}
0.3204 & 128.3394 & 15.5885
\end{array}\right]}
\end{aligned}
$$

Koefisien SVD di atas akan digunakan untuk membangun vektor observasi, namun nilai tersebut belum bisa dimodelkan oleh HMM sehingga harus dikuantisasi vektor menggunakan persamaan (4).

$\Delta_{i}=\frac{\left(\left[\begin{array}{lll}0.3204 & 3100145 & 46.9893\end{array}\right]-\left[\begin{array}{lll}0 & 1067848 & 14.3527\end{array}\right)\right.}{\left[\begin{array}{lll}18 & 10 & 7\end{array}\right]}$

$\Delta_{i}=\frac{\left[\begin{array}{lll}0.3204 & 203.2297 & 32.6366\end{array}\right]}{\left[\begin{array}{lll}18 & 10 & 7\end{array}\right]}$

$\Delta_{i}=\left[\begin{array}{lll}0.03204 & 20.32297 & 4.66237\end{array}\right]$

\begin{tabular}{|c|c|c|c|}
\hline Codebook 16 & Codebook 32 & Codebook 128 & Codebook 512 \\
\hline$\left[\begin{array}{llll}17 & 6 & 5\end{array}\right]$ & {$\left[\begin{array}{lll}1 & 7 & 7\end{array}\right]$} & {$\left[\begin{array}{lll}17 & 6 & 5\end{array}\right]$} & {$\left[\begin{array}{lll}17 & 8 & 2\end{array}\right]$} \\
\hline$\left[\begin{array}{lll}5 & 7 & 6\end{array}\right]$ & {$\left[\begin{array}{lll}5 & 7 & 5\end{array}\right]$} & {$\left[\begin{array}{lll}5 & 7 & 6\end{array}\right]$} & {$\left[\begin{array}{lll}5 & 9 & 3\end{array}\right]$} \\
\hline$\left[\begin{array}{lll}5 & 6 & 5\end{array}\right]$ & {$\left[\begin{array}{lll}5 & 7 & 5\end{array}\right]$} & {$\left[\begin{array}{lll}5 & 6 & 6\end{array}\right]$} & {$\left[\begin{array}{lll}5 & 8 & 3\end{array}\right]$} \\
\hline$\left[\begin{array}{lll}5 & 6 & 5\end{array}\right]$ & {$\left[\begin{array}{lll}5 & 6 & 4\end{array}\right]$} & {$\left[\begin{array}{lll}5 & 6 & 5\end{array}\right]$} & {$\left[\begin{array}{lll}5 & 8 & 3\end{array}\right]$} \\
\hline$\left[\begin{array}{lll}5 & 5 & 4\end{array}\right]$ & {$\left[\begin{array}{lll}5 & 6 & 4\end{array}\right]$} & {$\left[\begin{array}{lll}4 & 5 & 5\end{array}\right]$} & {$\left[\begin{array}{lll}4 & 7 & 3\end{array}\right]$} \\
\hline$\left[\begin{array}{lll}5 & 5 & 4\end{array}\right]$ & {$\left[\begin{array}{lll}5 & 5 & 4\end{array}\right]$} & {$\left[\begin{array}{lll}4 & 5 & 5\end{array}\right]$} & {$\left[\begin{array}{lll}4 & 6 & 3\end{array}\right]$} \\
\hline$\left[\begin{array}{lll}5 & 5 & 4\end{array}\right]$ & {$\left[\begin{array}{lll}5 & 5 & 3\end{array}\right]$} & [ $\left.\begin{array}{lll}4 & 4 & 4\end{array}\right]$ & {$\left[\begin{array}{lll}4 & 6 & 3\end{array}\right]$} \\
\hline$\left[\begin{array}{lll}5 & 4 & 4\end{array}\right]$ & {$\left[\begin{array}{lll}5 & 5 & 3\end{array}\right]$} & [ $\left.\begin{array}{lll}4 & 4 & 4\end{array}\right]$ & {$\left[\begin{array}{lll}5 & 5 & 2\end{array}\right]$} \\
\hline$\left[\begin{array}{lll}5 & 4 & 3\end{array}\right]$ & {$\left[\begin{array}{lll}5 & 5 & 3\end{array}\right]$} & {$\left[\begin{array}{lll}4 & 3 & 3\end{array}\right]$} & {$\left[\begin{array}{lll}5 & 5 & 2\end{array}\right]$} \\
\hline$\left[\begin{array}{lll}5 & 4 & 3\end{array}\right]$ & {$\left[\begin{array}{lll}5 & 4 & 2\end{array}\right]$} & {$\left[\begin{array}{lll}3 & 3 & 3\end{array}\right]$} & {$\left[\begin{array}{lll}5 & 5 & 2\end{array}\right]$} \\
\hline$\left[\begin{array}{lll}5 & 4 & 3\end{array}\right]$ & {$\left[\begin{array}{lll}5 & 4 & 2\end{array}\right]$} & {$\left[\begin{array}{lll}2 & 2 & 2\end{array}\right]$} & {$\left[\begin{array}{lll}5 & 4 & 2\end{array}\right]$} \\
\hline$\left[\begin{array}{lll}5 & 3 & 3\end{array}\right]$ & {$\left[\begin{array}{lll}5 & 4 & 2\end{array}\right]$} & {$\left[\begin{array}{lll}1 & 2 & 2\end{array}\right]$} & {$\left[\begin{array}{lll}5 & 4 & 2\end{array}\right]$} \\
\hline$\left[\begin{array}{lll}6 & 3 & 3\end{array}\right]$ & {$\left[\begin{array}{lll}6 & 4 & 2\end{array}\right]$} & {$\left[\begin{array}{lll}0 & 1 & 2\end{array}\right]$} & {$\left[\begin{array}{lll}5 & 4 & 2\end{array}\right]$} \\
\hline$\left[\begin{array}{lll}6 & 3 & 2\end{array}\right]$ & {$\left[\begin{array}{lll}6 & 4 & 1\end{array}\right]$} & {$\left[\begin{array}{lll}4 & 1 & 3\end{array}\right]$} & {$\left[\begin{array}{lll}5 & 3 & 2\end{array}\right]$} \\
\hline$\left[\begin{array}{lll}7 & 3 & 2\end{array}\right]$ & {$\left[\begin{array}{lll}7 & 4 & 1\end{array}\right]$} & 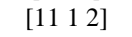 & {$\left[\begin{array}{lll}5 & 3 & 2\end{array}\right]$} \\
\hline$\left[\begin{array}{lll}7 & 3 & 2\end{array}\right]$ & {$\left[\begin{array}{lll}7 & 4 & 1\end{array}\right]$} & 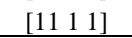 & {$\left[\begin{array}{lll}6 & 3 & 1\end{array}\right]$} \\
\hline
\end{tabular}

Setelah diketahui nilai $i$, komponen $x_{i}$ akan digantikan dengan nilai kuantisasi yang diperoleh menggunakan persamaan (5).

$$
\begin{aligned}
& q_{1}=\frac{\left[\begin{array}{lll}
0 & 255.0863 & 38.5746
\end{array}\right]-\left[\begin{array}{lll}
0 & 106.7848 & 14.3527
\end{array}\right]}{\left[\begin{array}{lll}
0.03204 & 20.32297 & 4.66237
\end{array}\right]}
\end{aligned}
$$

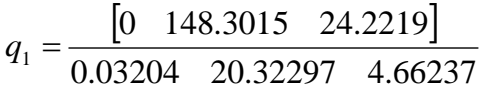

$$
\begin{aligned}
& q_{1}=\left[\begin{array}{lll}
0 & 7.3 & 5.2
\end{array}\right] \\
& q_{1}=\left[\begin{array}{lll}
0 & 7 & 5
\end{array}\right]
\end{aligned}
$$

TABEL 5 BASIS DATA HMM SAMPEL S1

Dengan cara perhitungan sama, maka didapatkan nilai kuantisasi blok_2 sampai blok_9 sebagai berikut.

$$
\begin{array}{ll}
q_{2}=\left[\begin{array}{lll}
9 & 9 & 7
\end{array}\right] & q_{3}=\left[\begin{array}{lll}
7 & 10 & 7
\end{array}\right] \\
q_{4}=\left[\begin{array}{lll}
7 & 0 & 0
\end{array}\right] & q_{5}=\left[\begin{array}{lll}
7 & 0 & 0
\end{array}\right] \\
q_{6}=\left[\begin{array}{lll}
8 & 1 & 0
\end{array}\right] & q_{7}=\left[\begin{array}{lll}
9 & 1 & 1
\end{array}\right] \\
q_{8}=\left[\begin{array}{lll}
9 & 1 & 1
\end{array}\right] & q_{9}=\left[\begin{array}{lll}
10 & 1 & 0
\end{array}\right]
\end{array}
$$

Proses perhitungan yang terakhir adalah perhitungan nilai label sesuai dengan persamaan yang sudah dimasukkan ke dalam program dari blok_1 sampai dengan blok_9, yaitu:

label $=q_{t_{1}} \times 10 \times 7+q_{t_{2}} \times 7+q_{t_{3}}+1$

Dengan menggunakan persaman (6), nilai label blok_1 sampai blok_9 adalah sebagai berikut.

$$
\begin{aligned}
& \text { label }_{1}=0 \times 10 \times 7+7 \times 7+5+1=55 \\
& \text { label }_{2}=9 \times 10 \times 7+9 \times 7+7+1=701 \\
& \text { label }_{3}=7 \times 10 \times 7+10 \times 7+7+1=708 \\
& \text { label }_{4}=7 \times 10 \times 7+0 \times 7+0+1=491 \\
& \text { label }_{5}=7 \times 10 \times 7+0 \times 7+0+1=491 \\
& \text { label }_{6}=8 \times 10 \times 7+1 \times 7+0+1=568 \\
& \text { label }_{7}=9 \times 10 \times 7+1 \times 7+1+1=702 \\
& \text { label }_{8}=9 \times 10 \times 7+1 \times 7+1+1=702 \\
& \text { label }_{9}=10 \times 10 \times 7+1 \times 7+0+1=708
\end{aligned}
$$

\section{E. Hasil Pengujian HMM}

Pengujian HMM berkaitan erat dengan codebook. Pada saat pengujian parameter HMM, maka coedebook harus dalam keadaan aktif. Sampel yang digunakan di HMM juga harus sama dengan sampel yang tertera di codebook. Hasil pengujian HMM berupa basis data matrik dari sampel yang sesuai dengan ukuran codebook 
TABEL 6

Hasil Pengujian Pengenalan Gangguan Ginjal SAMPEL TRAIN

\begin{tabular}{ccccccc}
\hline No & $\begin{array}{c}\text { Code } \\
\text { book } \\
\text { Sampel }\end{array}$ & $\mathbf{1 6}$ & $\mathbf{3 2}$ & $\mathbf{1 2 8}$ & $\mathbf{5 1 2}$ \\
\hline 1 & T1 & GGK & GGA & GGA & GGA \\
2 & T2 & GGA & GGA & GGA & GGA \\
3 & T3 & GGA & GGA & GGA & GGA \\
4 & T4 & GGA & GGA & GGA & GGA \\
5 & T5 & GGK & GGA & GGK & GGK \\
6 & T6 & GGA & GGK & GGK & GGK \\
7 & T7 & GGK & GGK & GGK & GGK \\
8 & T8 & GGK & GGK & GGK & GGK \\
9 & T9 & Negatif & BG & BG & BG \\
10 & T10 & BG & BG & BG & BG \\
11 & T11 & BG & BG & BG & BG \\
12 & T12 & Negatif & BG & BG & BG \\
13 & T13 & KM & KM & KM & KM \\
14 & T14 & BG & BG & KM & KM \\
15 & T15 & Negatif & Negatif & Negatif & Negatif \\
16 & T16 & BG & Negatif & Negatif & Negatif \\
\hline
\end{tabular}

yang digunakan. Basis data yang akan ditampilkan adalah basis data berupa matrik dari sampel S1, S2, S3, S4 dan S5. Basis data pada proses ini dapat dilihat pada Tabel 5 untuk sampel S1.

\section{F. Hasil Pengujian Pengenalan}

Tabel 6 menampilkan hasil pengujian akhir, yaitu proses pengenalan. Dapat dilihat bahwa 16 sampel yang diuji dikenali dengan baik oleh software pengenalan gangguan ginjal. Pada pengujian juga digunakan variasi ukuran codebook, yaitu 16, 32, 128 dan 512. Pada saat ukuran codebook 16, ada 5 sampel tes yang salah dikenali (gagal dikenali). Begitupula pada saat ukuran codebook 32, ada 2 buah kesalahan, yaitu pada sampel T5 dan T14. Pada T5 seharusnya dikenali sebagai GGK namun saat pengenalan dikenali sebagai GGA. Hal ini dikarenakan sampel GGA dan GGK ada kemiripan, sehingga pada saat ukuran codebook yang kecil tidak dikenali dengan baik. Sedangkan T14 adalah sampel dengan gangguan KM, namun pada saat pengujian dikenali sebagai BG. Hal ini bisa saja disebabkan oleh sampel yang kurang jelas. Saat ukuran codebook 128 dan 512 tidak ada kesalahan dalam proses pengenalan. Hal ini menunjukkan bahwa semakin besar ukuran codebook hasil pengenalan akan semakin baik. Hal ini karena codebook akan mempengaruhi matrik HMM. Semakin besar ukuran codebook, maka akan semakin detail matrik yang dihasilkan oleh metode HMM, sehingga proses pengenalan juga semakin baik. Namun penggunaan ukuran codebook yang semakin besar akan berakibat pada waktu proses pengenalan yang akan semakin lama.

Tabel 7 adalah hasil pengujian untuk sampel uji yang diambil dari orang-orang yang belum pernah
TABEL 7

Hasil Pengujian Pengenalan Gangguan Ginjal Sampel UjI

\begin{tabular}{|c|c|c|c|c|c|}
\hline No & $\begin{array}{c}\text { Code } \\
\text { book }\end{array}$ & 16 & 32 & 128 & 512 \\
\hline 1 & Uji 1 & Negatif & Negatif & Negatif & Negatif \\
\hline 2 & Uji 2 & Negatif & Negatif & Negatif & Negatif \\
\hline 3 & Uji 3 & Negatif & Negatif & Negatif & Negatif \\
\hline 4 & Uji 4 & Negatif & Negatif & Negatif & Negatif \\
\hline 5 & Uji 5 & Negatif & Negatif & Negatif & Negatif \\
\hline 6 & Uji 6 & Negatif & Negatif & $\mathrm{KM}$ & KM \\
\hline 7 & Uji 7 & KM & KM & KM & KM \\
\hline 8 & Uji 8 & $\mathrm{KM}$ & $\mathrm{KM}$ & KM & $\mathrm{KM}$ \\
\hline 9 & Uji 9 & GGK & GGK & GGK & GGK \\
\hline 10 & Uji 10 & GGA & GGK & GGK & GGK \\
\hline 11 & Uji 11 & GGA & GGK & GGK & GGK \\
\hline 12 & Uji 12 & $\mathrm{KM}$ & $\mathrm{KM}$ & $\mathrm{KM}$ & $\mathrm{KM}$ \\
\hline
\end{tabular}

berkonsultasi tentang kesehatan ginjal dengan variasi umur. Berdasarkan hasil tersebut, seseorang dengan rentang umur 36-60 tahun (sampel uji 7-16) berpotensi lebih tinggi terkena gangguan ginjal, sedangkan pada

rentang umur 10-35 tahun (sampel uji 1-6) ginjal dalam kondisi normal, kecuali sampel uji 6. Pada sampel uji 6 dengan rentang umur 26-35 tahun, menunjukkan hasil yang berbeda. Ketika codebook 16 dan 32 hasil menunjukkan negatif, sedangkan ketika codebook 128 dan 512 hasilnya adalah KM. Hal ini dapat dikatakan sebagai kegagalan pengenalan gangguan ginjal. Begitupula dengan sampel uji 10 dan 11, ada salah pengenalan pada saat ukuran codebook 16. Hal ini dapat disebabkan oleh adanya kemiripan sampel GGA dan GGK, namun ketika codebook diperbesar sampel dapat dikenali dengan baik.

Berdasarkan hasil uji pengenalan gangguan ginjal pada Tabel 6, maka dapat dihitung tingkat akurasi proses pengenalan untuk masing-masing ukuran codebook, dengan jumlah sampel train 16 sampel, seperti pada Tabel 8. Pada Tabel 8 dapat dilihat bahwa saat ukuran codebook 16, akurasi yang didapat adalah $68.75 \%$ dan saat ukuran codebook 32, akurasi yang didapat adalah $87.5 \%$. Hal ini menunjukan bahwa dengan menggunakan ukuran codebook kecil, maka kemungkinan proses pengenalan mengalami banyak kegagalan. Hal ini karena bit-bit yang dihasilkan adalah bit dengan range kecil, sehingga kurang detail dalam proses pengenalan. Namun dengan penggunaan ukuran codebook yang kecil tidak memerlukan waktu yang lama dalam proses pengenalan. Pada Tabel 8 dapat dilihat bahwa semakin besar ukuran codebook, maka persentasi akurasi pengenalannya akan semakin besar pula, walaupun membutuhkan waktu yang cukup lama dalam proses pengenalan. 
TABEL 8

TingKat AKurasi Pengenalan SAMPEl Train

\begin{tabular}{cccccc}
\hline Codebook & $\mathbf{1 6}$ & $\mathbf{3 2}$ & $\mathbf{1 2 8}$ & $\mathbf{5 1 2}$ \\
\hline Tingkat Akurasi (\%) & 68.75 & 87.5 & 100 & 100 \\
\hline
\end{tabular}

TABEL 9

TingKat AkURasi Pengenalan SAmpel Uji

$\begin{array}{lllllll}\text { Codebook } & 16 & 32 & 128 & 512\end{array}$

\begin{tabular}{llclll}
\hline Tingkat Akurasi (\%) & 75 & 91.67 & 100 & 100 \\
\hline
\end{tabular}

Berdasarkan hasil uji pengenalan gangguan ginjal pada Tabel 7, maka dapat dihitung tingkat akurasi proses pengenalan untuk masing-masing ukuran codebook, dengan jumlah sampel uji 12 sampel, seperti pada Tabel 9. Pada Tabel 9 dapat dilihat bahwa nilai akurasi pengenalan dengan sampel uji cukup tinggi meskipun masih ada kesalahan pengenalan pada saat ukuran codebook 16 dan codebook 32. Namun kesalahan yang terjadi tidak terlalu besar dibandingkan dengan pengujian sampel train.

\section{Penutup}

\section{A. Kesimpulan}

1. Waktu yang dibutuhkan untuk proses pengenalan gangguan ginjal pada sampel train rata-rata untuk ukuran codebook 16, 32, 128, 256 dan 512 masing masing adalah 2.925 detik, 3.025 detik, 3.5 detik, 5.15 detik, dan 25.45 detik.

2. Waktu yang dibutuhkan untuk proses pengenalan gangguan ginjal GGA, GGK, BG, KM pada sampel train rata-rata masing masing adalah 6 detik, 7.86 detik, 8.36 detik, dan 9.82 detik.

3. Akurasi yang diperoleh pada pengenalan sampel train dengan variasi ukuran codebook 16, 32, 128 dan 512 adalah $68.75 \%, 87.5 \%, 100 \%$, dan $100 \%$.

4. Akurasi yang diperoleh pada pengenalan sampel uji dengan variasi ukuran codebook 16, 32, 128 dan 512 adalah $75 \%, 91.67 \%, 100 \%$ dan $100 \%$.

\section{B. Saran}

1. Pengambilan sampel sebaiknya menggunakan kamera yang lebih canggih untuk menghasilkan basis data yang lebih baik.

2. Penggunaan metode selain Hidden Markov Model dalam proses pengujian dan penambahan sampel pengujian.

\section{REFERENSI}

[1] Trihono, "Riset Kesehatan Dasar", Badan Penelitian dan Pengembangan Kesehatan Kementerian Kesehatan RI, Jakarta, 2013.

[2] Y-W Lim, S-I Park, Y-J Park, Y-B Park, "A Review of Iridology", The Journal of The Society of Korean Medicine Diagnostics, Volume 17, No.1, halaman 1-16, 2013.

[3] R. Passarella, Erwin, M. Fachrurrozi, Sutarno, "Development of Iridology Basis data for Colon Disorder Identufication Using Image Processing", Indian Journal of Bioinformatics and Biotechnology, Vol 2(6), halaman 100-103, 2013.

[4] B. Setiawan, "Identifikasi Iris Mata Menggunakan Metode Hidden Markov Model”, Skripsi, Program Studi Teknik Elektro, Fakultas Teknik, Universitas Indonesia, Depok, 2009.

[5] Sherif E. Hussein, Osama A. Hassan, Malcolm H. Granat, "Assesment of the Potential Iridology for Diagnosing Kidney Disease Using Wavelet Analysis and Neural Networks", Biomedical Signal Processing and Control 8, halaman 534-541, Elsevier Ltd., 2013.

[6] Rita M. Holl, "Iridology: Another Look", Alternative Health Practitioner, Vol. 5, No. 1, Springer Publishing Company, 1999.

[7] B. Jensen, "What is Iridology", Ben Jensen Enterprise Publishers, California, 1982.

[8] __, "Iridology Chart", Maikong Industry, http://www.iriscope.org/iridologychart/iridology-chart-2, diakses Oktober 2019.

[9] Basuki P. Purnomo, "Dasar-dasar Urologi”, Edisi Ketiga, Sagung Seto, Jakarta, 2014.

[10] R. C. Gonzalez, R.E. Woods, "Digital Image Processing Second Edition", Prentice Hall, New Jersey, 2002.

[11] T. Sutoyo, E. Mulyanto, V. Suhartono, O. D. Nurhayati, "Teori Pengolahan Citra Digital", Penerbit ANDI, Yogyakarta, 2009.

[12] A. P. Lestari, "Rancang Bangun Pengenalan Penyakit Darah Menggunakan Metode Hidden Markov Model", Tesis, Universitas Indonesia, Depok, 2008.

[13] H. Miar-Naimi, P. Davari, "A New Fast and Efficient HMM-Bassed Face Recognition System Using a 7-State HMM Along With SVD Coefficien", Iranian Journal of Electrical and Electronic Engineering, Vol 4, Nos. 1 \& 2, halaman 46-57, 2008. 